\title{
Managing race relations' tensions in multicultural societies: a case study of Bradford in Britain
}

\author{
Hassen Zriba \\ University of Gafsa, Tunisia
}

\section{Introduction}

Multiculturalism has become a tricky issue in major western societies; there have been many demands to either stifle multicultural propensities or tailor them to the needs of host societies. The increasing civil disturbances and social instabilities alarmed respective western governments to advance alternative neo-assimilationist discourses and strategies that background multicultural narratives while foreground social "cohesionist" ones. This article scrutinizes the situation of the race relations in contemporary Britain with a special focus on 2001 race riots. The locality of Bradford is selected as a case study. This choice is enhanced by the fact that Bradford is one of the most multi-ethnic and multicultural cities in Britain. Moreover, it witnessed the worst race-related riots in contemporary Britain.

Race relations have been a prime concern of late 20 th and early $21^{\text {st }}$ centuries British governments. The 2001 race-related riots in Bradford were regarded as the outcome of inter-ethnic lack of communication. Thus residential segregation in the city was both a trigger and consequence of the lack of intercultural separation and mutual ignorance. A local race-related report known as the Ouseley Report was produced to diagnose the problem and to prescribe a solution. Consequently, it is suggested that the Ouseley Report was in many respects a hegemonic ideological text that was decoded differently by other conflicting ideological agents.

As far as the method of analys is is concerned, the present article employs critical discourse analysis. Such qualitative method best fits the arguments of the article since it offers analytical frameworks that decipher the ideologies and policies behind the creation of the Ouseley Report. The article uses a critical interpretive approach to analyze the discourses produced by the Ouseley Report and its critical reception.

The article is divided into five parts. In the first section, some models of integrating ethnic minorities are briefly reviewed so as to highlight the controversies surrounding the position of ethnic minorities in contemporary Britain. The second 
section provides an historical overview on the situation of race relations in Bradford and a brief survey of the 2001 race riots in Bradford. The third part is a close scrutiny of the Ouseley Report's community cohesion-oriented discourses while the fourth part will offer critical reception and decoding of the report itself. Also, in the last part, recommendations and possible prospects for future research are stated.

\section{Mode ls of integrating ethnic minorities in post-war B ritain:}

The integration of British ethnic minorities has been a pressing need for post-war British successive governments. Different approaches have been introduced to offer solutions to real and perceived race-related "threats". Consequently a plethora of theoretical and political projects has been suggested which tried to account for the process of integrating and dealing with race relations in Britain (Favell, 2001). The "Immigration-Integration Model" (Richardson and Lambert, 1998) which was based on the pivotal conservative idea that given enough time immigrants would ultimately assimilate within the socio-cultural fabric of British society, was produced in accordance with the assimilationist politics of immediate post-war Britain. The model was built upon the following major premises:

1- Britain is a stable mono-cultural society.

2- Immigrants are aliens by virtue of their alien cultures.

3- Such aliens would trigger social unrest and instability.

4- When given time immigrants would submerge into mainstream culture and adopt its values and ways of life.

5- When such assimilation takes place social stability and peace will be restored and national identity confirmed.

This paradigm clearly shows how cultural resemblance and homogeneity were so central to the constructions of the post-war national identity. Thus cultural difference was relegated to a marginal position. Difference was excluded from socio-cultural constructions of British national identity. Those immigrants who came from diverse cultures and countries were represented and essentialized in monolithic and static stereotypes. They were indifferently constructed as alien and a potential threat to a widely-believed in homogenized and well-defined national identity. The conservative politician Enoch Powell went as far as to represent immigrants and mainly their offspring as "rivers of blood" in his notorious speech with the same title. He warned: 
"We must be mad, literally mad, as a nation to be permitting the annual inflow of some 50,000 dependants, who are for the most part the material of the future growth of the immigrant-descended population. It is like watching a nation busily engaged in heaping up its own funeral pyre" (Powell, 1968: 14-19).

Eminent politicians such Margret Thatcher expressed the same discourse. The passage of the Nationality Act in 1981 was to be seen as a reinvigoration of British nationalism. The conflicts with the European Commission as well as the events of the Falkland war were "excellent occasions" of displaying nationalist tendencies and indulging a belief in the common British identity. Being in a state of war, the Thatcher conservative governments were able to capitalize on the uniqueness and imperialist heritage of the former British Empire. Once again the nation had an opportunity to revitalize its imperial history and stress the myth of common and unique origin. Such assimilationism-oriented ideological and political trajectories were largely intended to subdue any potential race-related "troubles" in the form of civil disturbance and social unrest. However, violent clashes like those generally known as Brixton Events (1981) evinced that racial and ethnic tensions were ineluctable if no alternative policies were taken. The conservative ideologies of asiimilationism proved a spectacular failure. The alternative came with the advent of the New Labour in 1997 with its anti-exclusion agenda and the anti-racism discourses.

Within such liberal progressive agenda, the Runnymede Trust published a report entitled The Future of Multicultural Britain (2000) also known as Parekh Report which, unlike the assimilationist version, constructed British identity in terms of cultural diversity and ethnic heterogeneity. The report was the outcome of a longitudinal investigation of the contemporary state of race relations in Britain. A group of eminent and diverse contributors chaired by Professor Bhikhu Parekh stated their views and understandings of the past, present and future realities of race relations and Britishness. The first part entitled "A Vision for Britain" is of vital importance since it tries to rethink the foundations and contours of British identity. The report in general was engaged in revising and "Rethinking the National Story" so as to highlight its inclusive and multi-ethnic character. The report stresses the fact that Britain just like all other nations and communities is an "imagined community". Such "imagined-ness" is set against the essentialist and static conceptions and constructions of national identities. The logic is that if the nation is imagined it can be re-imagined. The identities out of which the community is composed are in a state of flux or to use the report's phrase "identities in transition" (Parekh, 2000: 27) . Historically, the report shows that all the historical events and acts, upon which an understanding of traditional Britishness was based, were neither unanimous nor 
unproblematic. For instance, the Act of Settlement (1701) and the Act of Union (1801) were, according to the report, "continually contested". Parekh criticized the unidirectional and race-oriented concept of Britishness. He stressed that conventional and traditional conceptualizations of the notion/nation were systematically constructed to include the mainstream white majority while excluding the other non-white minorities. He wrote:

"Britishness, as much as Englishness, has systematic, largely unspoken racial connotations", and he added that for those nonwhite minorities, whose native countries were once under the British imperial system, "Britishness is a reminder of colonization and empire"(Parekh: 38).

However, he argued that compared to Englishness, Britishness is a preferred source of identification for them as Englishness entails whiteness. Ethnic minorities tend to combine Britishness with other identities, thus, creating what can be called hyphenated identities such as British-Indians, British Muslims and so on. Parekh and his group considered that $21^{\text {st }}$ century Britain was at the crossroads regarding its identity. They declared:

"Brita in confronts a historic choice as to its future direction. Will it try to turn the clock back, digging in, defending old values and ancient hierarchies, relying on a narrow English-dominated, backward-looking definition of the nation? Or will it seize the opportunity to create a more flexible, inclusive, cosmopolitan image of itself? Britain is at a turning point. But it has not yet turned the corner. It is time to make the move"(Parekh: 15).

For Parekh the concept of Britishness is "less unified, more diverse and pluralistic, than imagined" (Parekh, p.36) which means that ethnic minorities with the ir diverse cultures can take a part and find a place in the imaginings of British national identity. Just as British national identity is dynamic and diverse so are those of ethnic minorities; they make up heterogeneous and multidimensional entities.

What Parekh laid down in his report was an attempt to refine and redefine the concept of Britishness to stress it pluralist and civic character. This would make the concept more dynamic and inclusive. Civic values were considered as the basis of this new Britishness. In multicultural Britain, cultural difference was recognized and thus there have been a gradual shift from a mono-cultural Britishness to a 
multicultural one. The report stressed six tasks that were to be addressed. These tasks were:

"** the need to rethink the national story and national identity;

* the need to recognise that Britain comprises a range of 'majority' and 'minority' communities which are internally diverse and which are changing;

* the need to strike a balance between the need to treat people equally, the need to respect the differences and the need to maintain shared values and social cohesion;

* the need to address and remove all forms of racism;

* the need to reduce economic inequalities;

* the need to build a pluralist human rights culture." "(Parekh: 265266).

Indeed, the Parekh Report was a turning point in the definition of British identity. It was to use Pilkington's phrase "Radical Hour"(Pilkington, 2003) in which a new reading of British identity and history was to emerge. According to Parekh, multiculturalism had to be acknowledged as an irreversible fact in contemporary Britain. The new multi-ethnic Britain was accordingly envisaged as a "community of communities and a community of citizens" (Parekh, 2000: 56). Such new conception seems to strike a balance between different concepts: cohesion, equality and difference. Thus Britain is a community that shares common values and conceptions of the world, but it is also composed of many communities which stress its diverse nature. This co-existence of cohesion (unity) and diversity (difference) seems to make the two ends meet: the majority is satisfied by cohesion and the minorities get their diversity recognized. The myth of ethnic essentialism and distinctiveness was debunked for the sake of a new conception of race relations. Andrew Pilkington wrote:

"Thinking of Britain as a community of communities challenges the conventional view of Britain as divided into two seemingly homogenous groupings, a White majority and ethnic minorities, and urges us instead to recognise that Britain comprises a number of fluid, overlapping and internally diverse national, regional and ethnic communities which cut across any simple majority/minority division" (Pilkington' 2003'.

To conclude the Parekh Report was an attempt to revise race relations in contemporary Britain with a special focus on the irreversibility of the multicultural nature of the nation. With the formula of Britain as "a community of communities 
and a community of citizens", the report presented a new understanding of the cultural and ethnic realities that emphasize diversity while asking for a set of common values that preserve the inter-and intra-cohesiveness of Britain.

The above analyzed two paradigms (assimilationist and multiculturalist approaches) represent two different ways intended to cope with inter-ethnic relations. Perhaps the two theoretical models did not comprehensively cover and meet ethnic worries and anxieties, yet they highlighted the complexities and complicatedness of race relations in contemporary Britain. Bradford is an outstanding instance of such intricate and tricky race-related issues.

\section{Race-re late d experience of $B$ radford:}

Being a multi-ethnic and multicultural city, Bradford has been a notorious centre of inter-ethnic tensions; a decade after the 2001 race riots the city is still at unease with its multicultural character (Bakare, 2011). According to journalist Lanre Bakare: "Bradford still faces challenges when it comes to relations between different communities" (Bakare, 2011). This persistent tensed race relations patterns seem endless. What follows is a brief historical consideration of the crucial development in the story of race relations in Bradford.

\section{- Local reality of race relations in Bradford:}

Generally, the history of Bradford race relations could be described and divided in four distinct phases: the "No Policy" phase (1960's-1980), the "Race Relations Policy" phase (1980-1991), the "Equal Rights" phase (1991-2000), and the "Cultural Diversity and Community Cohesion" phase (2001-2003). Those distinct phases should not be read as completely self-contained historical blocs. They form a continuum from community relations to the current community cohesion stage. They are different policies within one policy, by which we mean that all the race relations policies from the immediate post-war era to the present day have worked within the same political and ideological framework. The British state, being a pluralistic form of capitalism, has been trying to integrate newcomers into its socio-economic system to attain the necessary consensus for governability.

During the 1950's and the 1960's, the assimilationist model conceived Britain (and by analogy Bradford) as a cohesive nation knit together by a common language and culture, a sense of kinship and common descent, a shared view of history and a strong sense of national identity. Bradford was seen as an extended family with the same inherited institutions and loyalties, which were the source of such characteristic virtues as patriotism, public spirit solidarity and respect for the law. Such a view of Bradford made assimilationists protective about it and ethnic 
minorities were seen as a threat. Minorities, according to the assimilationists, "had only two choices, to get fully assimilated into the British society or to leave the country" (Parekh, 1998: 16). In that ideological climate, there was no room for prominority concessions. Minorities were expected to show their readiness to assimilate and adjust to the British culture and way of life. The relative absence of pro-minority procedures can be explained thus: it was a "No Policy" phase.

However, with the relative militancy of the South Asian ethnic minorities in Bradford, the situation began to change. In 1976, twenty-four people were arrested in pitched battles in the Manningham area of Bradford, when young Asians confronted a National Front march and fought police protecting it. The following year (1977), the Asian Youth Movement (AYM) was born. The next few years witnessed further conflicts between young Asians and the police, culminating in the trial of the "Bradford 12" in 1981. Twelve young Asians faced conspiracy charges for making petrol bombs to use against racists. They argued that they were acting in self-defence, and they won when the jury accepted this. That case, Ramindar Singh, commenting in the context of the Brixton riots, thought, "sent a clear message that it [Bradford] might also be sitting on a time bomb" (2002:2).

Faced with this growing militancy, Bradford Council drew up Greater London Council (GLC)-style equal opportunity statements, establishing race relations units, and began its race relations policy with all the procedures and measures mentioned above. The Bradford Council initiated its multi-cultural policy by encouraging each ethnic group to promote its language, culture, religion and identity. However, such multi-cultural policies were undermined by the notorious Honeyford Affair and Satanic Verses incidents, which caused suspicion and resentment in inter- and intra-ethnic minority relations.

Presumably, the turbulence of the mid and late 1980's contributed to a change in Bradford local policies. In October 1991, the Council issued its Equal Rights Statement: a Fresh Start, to treat the issue of race within a wider equalitarian approach. The Council, having been perceived as racist and biased, wanted to show the opposite. The external consultant John Carr was commissioned by the Council to examine its handling of complaints of discrimination.

The Carr Report's findings referred to racial bias in the Legal Services Department. Nevertheless, according to Mahony, "the Council had made a big issue of Carr's involvement so as to be seen doing something while avoiding the key findings" ( 3 ). Whether Mahony's opinion was true or false is not very important. What is important was the general perception of the local authorities' lack of clear vision and well-organised policy. 
Such an assumption seemed to be confirmed by the 1995 Manningham riots, widely seen as the product of no clear vision or strategy (see Telegraph \& Argus, November, 21, 1996). The local authorities paid more 'interest and attention' after the publication of the Macpherson Report in 1999, and the passage of the Race Relations (Amendment) Act in 2000, which imposed new obligations on local authorities to take positive action and promote race relations. Bradford V is ion was the product of that legislative requirement.

\section{- The 2001 Bradford's disturbances:}

Riots erupted on July 7 and lasted until July 9, 2001. The ir general background included a series of incidents in the Lidget Green area of Bradford and in other northern cities (Burnley on 24-26 June, Oldham on 26-29 May) during the previous few weeks. However, the immediate context was supplied by the cancelling of the Bradford Festival planned for July 7, because of police fears about an intervention by the British National Party (BNP).

A spasm of violence shook Bradford on the night of July 7: about 400-500 people were active on the streets armed with a variety of weapons. Fires were started, and some stabbings occurred, including attacks on police horses. Damage to property was enormous, estimated at £7.5-10 million. 326 police officers were injured, and occupants' lives were placed at risk (Samad et al, 2002: 9). The July events had been preceded by comparatively minor violence at Easter. John Denham, Chairman of the Ministerial Group on Public Order and Community Cohesion, in the report Building Cohesive Communities (2001) provided along with other researchers statistical figures about the damage caused by those events.

\begin{tabular}{|c|l|l|}
\hline & B radford Eas ter & B radford July \\
\hline $\begin{array}{l}\text { Numbers involved } \\
\text { in disorders }\end{array}$ & Approximately 100 & $400-500$ \\
\hline Injuries & $\begin{array}{l}\text { No police injured, 20 } \\
\text { members of the general } \\
\text { public }\end{array}$ & $\begin{array}{l}\text { 326 police injured, 14 } \\
\text { members of the general } \\
\text { public }\end{array}$ \\
\hline Cost of damage & Estimated at £117,000 & Estimated at £7.5-10 million \\
\hline
\end{tabular}

Table 1: Comparis on of violence in Eas ter and July 2001 in B radford (Denham:7)

The factual evidence on the disorders was obtained from the local police: the Greater Manchester Police, the West Yorkshire Police and the Lancashire Constabulary (2001). 
The July events were "the worst in 20 years" (Denham et al, 2001: 7). Jan-Khan (spokesman for Manningham residents) considered them as "the worst seen in mainland Britain" (Jan-Khan: 12). The events were dramatic and shocking, marring Bradford's public image, "and once again this City has become the symbol of ethnic tension, brutal racism, failed integration, and miserably inadequate innercity policies" commented Yasmin Alibhai-Brown, the partisan journalist and broadcaster on race and cultural issues (1).

A plethora of explanations was given to explain the events, each of which handled the issue from a different perspective. From an official point of view, the events reflected the lack of communication between ethnic communities. The selfsegregation of the ethnic minorities reinforced this ignorance of the others. Such "voluntary self-segregation" promoted racial tension and demoted any genuine communication; "disturbances occurred in areas which had become fractured on racial, generational, cultural and religious lines and where there was little dialogue, or much contact, between the various groups across those social divides" (Denham et al: 8). They were also seen as the product of deprivation, poverty and youth alienation. Almost the same message was conveyed by academics. Yunas Samad (University of Bradford) identified a cluster of background factors: socio-economic deprivation, racism and social segregation, and social identity and social division (Samad et al, 2002: 6-7).

In December 2001, the Cantle Report was published as an official response to the riots. It represented and defined the Government's strategy for mainta ining order in the northern towns. Defining the problem as one of social and geographical segregation, Ted Cantle suggested that the population of those rioting towns (white and minorities) were living "parallel lives" (9) that prevented them from meeting and negated any common values or similarities. The solution, proposed by Ted Cantle and his group, was to develop "a greater acceptance of the principal national institutions" (Cantle: 19), which was believed to result in community cohesion.

Arun Kundnani provided a somewhat different explanation. In his article "From Oldham to Bradford: The violence of the violated" for the Institute of Race Relations, he considered ethnic segregation as "forced" not "self-imposed". This was backed by some statistical figures: "out of Bradford's large stock of Council housing, just $2 \%$ has been allocated to Asians". He saw the ethnic minorities' segregation as the product of the "fear of racial harassment (which) meant that most Asians sought the safety of their own areas" (all quotations from 2001: 105).

As far as Bradford was concerned, the Ouseley Report, also known as Community Pride not prejudice (July 2001)' was the manifesto of the local authorities. It tried 
to make "[D]iversity work in Bradford" (the title) by focusing on the problem of ethnic minorities and their "drift towards self-segregation" (Foreword I). The following section considers the Report and its reception in greater detail.

\section{The Ouseley Report}

In response to the Race Relations (Amendment) Act of 2000, Bradford Vision (BV) invited Sir Herman Ouseley to chair the new, independent Review Panel to investigate the generally perceived "deteriorating" race relations in the District. The Bradford Race Review was promoted by a number of concerns including the changing national picture and the need to provide a new, permanent racial equality service after the closure of the Bradford Race Equality Council (BREC) in 2000.

The declared goals of the Bradford Race Review Panel (BRRP) were to

1-identify shared concerns and understandings in order to build bridges between communities where they do not exist or strengthen them where they are weak

2-identify issues which cause conflict between individuals and communities on the grounds of race, culture and religion and suggest ways of resolving them

3-identify ways of working which will help public, private, voluntary and faith organisations to promote greater understanding and respect between communities

4-consider whether the district needs a racial equality organisation; if so, what form it should take. (BRRP, 2001: 1)

It was the task of the Race Review Panel, under the chairmanship of Sir Herman Ouseley, to launch such a project. And the above-mentioned goals were to be the blueprint of the Ouseley Report or, more accurately, Community Pride not prejudice.

\section{- The report: Community Pride not prejudice (2001)}

The wide experience of Sir Herman Ouseley in the field of race relations and minorities studies made Bradford's local authorities welcome him. Council leader Margaret Eaton (2001) said: "[W] e are pleased that Sir Herman has agreed to take on this important role and help Bradford find the best way of developing racial 
equality in the district... he has a national reputation in this field and will give the review a truly independent perspective" (Marketing and Communications Unit of BMDC, 2001).

Ian Greenwood, the Labour Group leader, and Jeannette Sunderland, Liberal Democrat Group leader, also expressed the same hope that Sir Herman Ouseley would help Bradford promote its community relations in accordance with the requirements of the Race Relations (Amendment) Act of 2000. The declared aim of the report was to make "[D]iversity Work in Bradford" (the title), to create and strengthen links and build bridges between the various communities in the District, and above all to help the people of Bradford get rid of their prejudices and be proud of being Bradfordians.

Structurally, the report contains two forewords in which Sir Herman Ouseley, the Chairman of Bradford Race Review Panel (BRRP), and Martin Garratt, the Chief Executive of Bradford Vision (BV), outline the report's goals and strategies. It includes six parts and two appendices, as follows:

1- The Bradford District Race Review

2- Bradfordian views of the District

3- People seeking solutions-projects to build on

4- Moving forward

A proposed Bradfordian programme to include:

I- Citizenship education in schools

II- Centre for Diversity, Learning and Living

III- A behavioural competency framework for the workplace

IV- Equality and diversity contract conditions

5- The national picture: Statutory duty on public bodies:

Race Relations (Amendment) Act 2000

6-Action plan

* Appendices: a) Expert inter-faith and inter-cultural education resources within Bradford District

b) Public bodies in 2001 and beyond

* Checklist for equality performance audits (see Ouseley Report, 2001: 48).

The report stressed that the already remarkable decline in the District's fortunes, resulting in deprivation and poverty, had produced emergent and growing divisions among the members of its population a long different lines: race, ethnicity, religion and social class. Those divisions and sub-divisions promoted a perceived and 
widespread feeling that Bradford is "in the grip of fear" (Ouseley: 1). The word "fear" appears throughout the report (in the first page, the word "fear" is used nine times). Throughout the report, the word "fear" and its derivatives and synonyms (fearful, frightening, phobia, Islamophobia, and homophobia) were used 21 times, and this reflects the 'morbid' nature of the report.

The Ouseley Report described the increasing self-segregation within Bradford's communities. Such polarization and self-segregation, the report stressed, were the outcome of an accumulation of mutual distrust and fear between the various local communities. People from different ethnic groups felt afraid of talking frankly about their problems, of managing change, of challenging wrongdoing and abuse, of crime and gang culture (and the list continues). This "culture of fear" (3), "blame culture" (12), "gangster culture" (19) made it difficult to initiate a "can-do culture" (3).

Such realities, as the report presented them, urged different ethnic groups to segregate "themselves into 'comfort zones' made up of people like themselves" (16). Such fear, failure, self-segregation and mistrust made people feel "that the District's qualities, assets and natural attractions were often undersold or overwhelmed by the negativity and notoriety which is too often associated with Bradford identity" (19).

Nevertheless, having analyzed Bradfordian views, the report offered some solutions to the problems of community division and dissension. A Bradfordian People Programme (BPP) was proposed, the aim of which was to build "trust and confidence across all communities" (24). The distinct features of this programme were as follows:

a- Citizenship education in schools: the aim of this type of education was to ensure that all pupils learn about diversity, and the need to respect people from different social, religious and cultural backgrounds

b- Centre for Diversity, Learning and Living: this would teach people how to share the benefits of diversity, and provide expertise, advice and guidance to all the District's institutions and organisations on a range of multi-ethnic issues

c- A behavioural competency framework for the workplace: it was to encourage all the organisations to make sure their staff were aware of the District's multi-cultural nature and needs. All employees should conform to new "standards of behaviour" and 
show a deep understanding of the socio-cultural backgrounds of the people they were dealing with

d- Equality and Diversity contract conditions: Equality and Diversity conditions must be inserted in all contracts of grant-aid, public-financed investment and other partnership projects to promote cultural and social mixing as well as good race relations. (Ouseley: 20)

Ouseley and his group put forward a number of recommendations, which, if put into effect, would create "a can-do culture" in place of the prevalent "culture of fear" (3). Some of the major recommendations were:

- To encourage and push vision and values which promoted the District's diverse multi-cultural programmes

- To highlight and build upon positive assets of the District in all socio-economic programmes

- To communicate overtly and frankly with local people and convince them of the benefits of the diverse multi-cultural nature of the District. This would and could be done through interacting and working together

- To prioritize children and young people as potential leaders in the District

- To promote citizenship education and establish centres for diversity and cultural awareness

- To ensure that all public bodies had independent Equality and Diversity Audits covering all activities.

Though the Ouseley Report tried to cover all aspects of community relations and "un-relations" in Bradford District, it had its apologists and its detractors. It was read and decoded differently either preferredly or oppositionally.

\section{- The critical reception of the Ouseley Report}

There have been conflicting opinions concerning the importance and relevance of the Ouseley Report. The different attitudes and decodings expressed different ideological perspectives. For instance, Phillip Lew is (2001), the Inter-Faith Advisor to the Anglican Bishop of Bradford and lecturer in Religious Studies at Leeds University, expressed a "mildly" positive opinion. For Lewis, the Report "is a landmark" as it "gives voice to all communities, not least young people, the 
vulnerable and the disaffected" (Lewis, 2001: 1). For Lewis, "the fast-growing Muslim community lives in "self-segregated" areas and "separation is consolidated" and mutual stereotypes go unchallenged in segregated - all-Asian or all-white - areas with little interaction or opportunity to learn about each other" (1). Lewis agreed with Ouseley that the lack of interaction and mutual ignorance were the basic causes of mutual refusal and "self-segregation".

Martin Garratt, the Chief Executive of Bradford V ision (BV), thanked Sir Herman Ouseley and the Race Review team for producing "a report which clearly captures the views of people across the District" (2001: Foreword 2 of the Ouseley Report).

The above views seem to be uncritical of the report. They take its comments and findings at face value. This can be attributed to the official positions their proponents hold. What they did was to repeat the local official discourse in the ir own tones. Obviously, Garratt, the Chief Executive of Bradford Vision, which commissioned the Review, would not criticize a report which absolved local authorities from the heaviest part of the responsibility. The same is true for the conservative religious discourse of Lewis, who, using the usual harmonious discourse to tackle the interwoven issues of race and the ethnic minorities' cultural backgrounds, repeated what the local authorities had said. Thus Muslims, unlike Hindus and Sikhs, were self-segregated and clustered into their "comfort zones". He highlighted the religious aspects of Muslim communities: "a self-sufficient religious and cultural world has been re-created: mosques and mosque schools, halal butchers, community centres reserved to men or women" (Lew is, 2001: 2). He interpreted the violence of 7-9 July as an expression of 'Muslim 'solidarity' against the BNP" (2).

Arguably, what Phillip Lewis, Martin Garratt and others, who uncritically accepted the findings of the Ouseley Report, seemed to do was to parrot the consensual official discourse. Such types of discourse were likely to hide other realities and make it difficult to identify problems, let alone seek solutions. "A benign Bradfordian multi-cultural 'harmony discourse' may obscure the extent and nature of racial exclus ion in the city and the labour market" (Husband: 18).

Nevertheless, there were more critical views. Frank Kimbal Johnson, the extremist nationalist writer, wrote in Spearhead, the journal of the National Front (NF), an article entitled "The Bradford Vision" (July 2001) in which he considered the Ouseley Report as a formula "to destroy our national identity, heritage and fundamental freedoms" (Johnson).

Johnson criticized one of the major recommendations of the report: the "citizenship education programme" to combat the "knowledge deficiency" from which 
Bradford seemed to suffer. The failure to set up and promote a multi-cultural atmosphere did not, in Bradford or elsewhere "arise from ignorance of alien cultures among the native British population but from our entirely legitimate desire to preserve British culture in towns and cities now subjected to large-scale invasion". Ouseley and his group were creating a concoction of disparate and conflicting ingredients:

...the Ouseley prescription seems to be forcible inter-mixing (to call it 'integration' is a grotesque euphemism) of disparate races plus intensive indoctrination of predominantly English schoolchildren in alien traditions and values. (Johnson, 2002)

Johnson's ideological stance (being a member of the BNP) was evident in his considering of the report. Thus, ethnic minorities were seen as "alien invaders" and their struggle for equality as "alien opportunism". They were "unwanted immigrants" who threatened to turn Brita in into "a colony of the Third World" (all the quotations from Johnson). Consequently, any reference to multi-culturalism, diversity and integration in the Ouseley Report was viewed as "multi-racial indoctrination" and liberal dogma.

Josie Appleton of Spiked Politics Online considered the report as "a prism through which to view the violence as the outbursts of a divided community". The report represented Bradford as a city composed of groups who refused to interact, and who needed official training to learn how to inter-mix. There was a sense of "communication breakdown" (1). The solution that the report advocated was to make different ethnic minorities aware of their own and other's cultural specificities. But Appleton's argument was that making each minority (especially children) aware of its distinctiveness was "likely to increase people's awareness of divisions, and corrode genuine existing relationships between people of different backgrounds...reinforce people's sense of difference from each other" (all the quotations from Appleton: 2).

The report's call to make employees multi-culturally aware through the proposed "[B]ehavioural competency framework for the workplace" (Ouseley: 32) would 'bureaucratize' genuine human relations; "when an Asian friend becomes a source of CV points to demonstrate 'diversity competence', an enjoyable friendship is transformed into a testing ground for your inter-cultural communication skills" (Appleton: 1).

The report's proposal that there should be "pre-determined acceptable behaviour" (Ouseley: 33) was criticized by Appleton as being unrepresentative of people's wishes "[W]ho pre-determines those acceptable behaviour standards...Certainly 
not the Bradfordians themselves" (Appleton: 2). Such behaviour standards could not work, since they were arbitrary and imposed from above.

The report, Appleton emphasized, depicted Bradfordians as people born with prejudice. And there was no other way to dispose of such prejudice except by improving their diversity competence. For Appleton, Community Pride not prejudice was "shameless social engineering" (3).

Equally critical was the attitude of Julie Hyland. As a member of the World Socialist Web Site (WSWS), she produced in July 2001 an article entitled "Britain: Bradford report shows the dead end of racially based politics". As the title shows, Hyland was committed to showing, from a Marxist perspective, that the problems of multi-ethnic cities could only be explained within a class perspective.

Though Hyland stated that Ouseley and his group had managed to identify the problem as being one caused by divisive multi-cultural politics and the Labour Party's politics of identity, she affirmed that the Report simply proposed more divisive programmes; "it [the report] blames public disenchantment with the misapplication of multiculturalism rather than the politics themselves" (7). Like Appleton, Hyland considered the Ouseley recommendations as "more divisive". The report's prescriptions "will do nothing to prevent the growth of poverty and racism, but will only foster further resentment between black and white workers" in a capitalist attempt to preserve the status quo and sow "division among working people". Thus, the Ouseley Report was part of a New Right strategy to eradicate unity and radicalism within the working class.

The riots were "the end result of the systematic efforts to undermine a unified solution to the common problems facing working people". If Ouseley thought that the solution to this fragmentation and self-segregation was more "cultural diversity awareness", Hyland affirmed that the solution consisted in fighting "for social equality, uniting all workers in defence of their jobs, living standards and democratic rights" that provide a "progressive way forward" (all the quotations from Hyland: 8).

In a word, the Ouseley Report (being the manifesto for racial equality for all the District's key institutions, including the BMC) was not received consensually. The different intellectual and ideological stances of those who commented on the report affected their reading of Bradford's disturbances and the report's findings and recommendations. Sir Herman Ouseley, Lewis and Garratt identified the selfsegregation of ethnic minorities as the cause and result of the violent ethnic clashes. Kimbal Johnson, a jingoistic nationalist, affirmed that "the basic cause of recent and most inner-city problems is a massive influx of unwanted immigrants 
from the Third World" (Johnson: 2). The socialist Julie Hyland insisted that the violence was a logical outcome of "deliberate means of sowing divisions among working people" (Hyland: 5).

Accordingly, the proposed solutions were strikingly different. The Ouseley camp encouraged more cultural awareness and social harmony. Johnson pleaded for English "children to resist any measures calculated to destroy our national identity and fundamental freedoms" (Ibid: 2). Hyland called for workers' unity and resistance to the 'capitalist conspiracy'.

However, these different, and even antithetical, views (I believe) were indicative of the delicate, complex nature of race relations in Bradford (and Britain generally). Such different pulls have made it a thorny task for the local Bradford authorities to address the interlocking and complex issues of class, gender and race. The recent equalitarian approach meant that the local authorities were to work collectively to build a new consensus on those tricky issues. Bradford Vision, the umbrella under which such an approach and project were to work, was only a vision (2020), and it is too early to assess either its success or failure. Community Pride not prejudice, whether a success or failure, is one reading of the situation only. Sir Herman Ouseley was conscious of the toughness of the mission. He stated that "there will be no gain without pa in" (Ouseley: 3). The above-stated critical views might be the beginning of the pain Sir Herman Ouseley had predicted.

\section{Recommendations}

The present study yielded a number of findings and recommendations. It revealed how delicate race relations are in contemporary Britain. Focusing on multiethnic and multicultural localities like that of Bradford can even present a clearer embodiment of such race-related tensions. Our critical discourse analysis of one major local document in post-2001 race riots (The Ouseley Report) showed that there is a need for more work and research to be done in this field. The deciphering of the different strategies and tools used in treating race relations in Britain is of paramount importance to understand the ideological and political mechanism used to manage race-related tensions. Equally important, additional research should concentrate on the national picture. Comparative studies have to be done in order to capture the multifarious aspects of race relations in Britain. 


\section{Conclusion}

The issues of integrating different ethnic minorities within contemporary multicultural societies came to the fore as top priorities. Britain is not an exception. The increasing multiethnic and multicultural nature of postwar British demography necessitated the adoption of diverse and sometimes incommensurable set of racerelated politics. The city of Bradford is a microcosm of the interethnic dialogues and tension. This article broached how such city came to terms with its inherent socio-cultural tension (often read as race-related). The 2001 race riots are an outstanding example of ethnic tensions in Britain and how they were discursively managed.

The Ouseley Report was meant to construct an emergent community cohesionbased discourse in post-2001 race relations Bradford. The report was also known as Community Pride not prejudice. It is interesting to notice that the adopted punctuation of the title of the report was semiotically prepared to capitalize on pride while diminishing the importance of prejudice. A hopeful message was conveyed: pride is what citizens of Bradford should feel not prejudice.

However, the events of July 2001 were indicative, perhaps, of the inadequacy of such a vision and its 'utopianism. The multicultural approach, declared by Herman Ouseley to be the solution to Bradford's problem, was seen by many critics (e.g. Kenan Malik, 2001, Arun Kundnani, 2001) as the problem. The 2001 riots were seen as the last 'nail' in the multicultural coffin. Seemingly, the official discourse of community cohesion and shared sense of "Britishness" is a good example of this new tendency.

\section{References and notes:}

- Alibhai-Brown, Y. (2001). "Bradford's Burning”, The Independent, 10 July. -Appleton, J. (2001). "After Bradford: engineering divisions”, Spiked-Politics Online, (http://www.spiked-online.com/printable 00000002D19A.htm), accessed in July, 10, 2007.

-Bakare, L. (2011). “A decade after the riots, Bradford is still uneasy about race relations”, The Guardian, July, $7^{\text {th }}$.

- Bradford Vision. (2001). The District 5 Year Community Strategy for Bradford 20002005 ,

Bradford 2020 Vision. Bradford District Summary Document: (http://www.bradford2020.com), accessed in October, $22^{\text {nd }} 2008$.

-Cantle, T. (2001). Community Cohesion: a Report of the Independent Review Team. London: Ho me Office. 
-Denham, J. (2001). Building cohesive communities: a report of the ministerial group on public order and community cohesion. London: Ho me Office.

Favell, A. (2001). Philosophies of Integration: Immigration and the Idea of Citizenship in France and Britain. New York: Palgrave.

-Husband, C. (2001). "Young People's Entry into the Labour Market in a Multi-ethnic City". Bradford: Bradford Vision, Section 4.

-Hyland, J. (2001). "Britain: Brad ford report shows the dead end of racially-based politics", World Socialist Web Site WSWS, (http://www.Org) accessed in October, 15, 2008

-Kundnani, A. (2001). "From Oldham to Bradford: the violence of the violated", in Race and Class, 43, 2: 105-131: Institute of Race Relations.

-Johnson, F.K. (2002). “The 'Bradford Vision”". Spearhead Online,

(http://www.spearhead-uk.com/0108-FKJ.html) accessed in October, $22^{\text {nd }} 2008$

-Jan-Khan, M. (2002). "The Right to Riot?" Standing Conference for Community Development SCCD News online.

-Lewis, P. (2001). "After September $11^{\text {th }}$ Bradford - more than a race war". The Diocese of Bradford, (http://www.brad ford.anglican.org), accessed in January, 22 2008.

-Macphers on, W. (1999). The Stephen Lawrence Inquiry: Report on Inquiry by Sir William Macpherson of Clung. London: HMSO. C42-62-I.

-Mahony, G.V. (2001). "Race Relations in Bradford”. Bradford: Bradford Vision, Section 7.

-Malik, K. (2001). "The trouble with multicultura lis m”. Spiked-Politics Online,

(http://www.spiked-on line.co m/articles/00000002D35E.htm) accessed in August, 9, 2008

-Ouseley, H. (2001). Community Pride not prejudice: Making Diversity Work in Bradford. Bradford: Bradford Vision.

-Parekh, B. (1998). "Integrating Minorities" in Blackstone, T., Parekh, B. and Sanders, P., Race Relations in Britain: a developing agenda. London: Routledge.

-Parekh, B. (2000). The Future of Multi-Ethnic Britain,.London: The Runnymede Trust.

-Pilkington, A. (2003). Racial disadvantage and Ethnic Diversity in Britain. London: Palgrave Macmillan.

-Powell, E. (1968). "Rivers of blood' speech in Birmingham in April 1968". The full text is in New Statesman, 17 April 1998.

-Richardson, J and Lambert, J. (1985). The Sociology of Race. Ormskirk: Causeway Press.

-Samad, Y., Burja, J., Carling, A., Lewis, P., Nias, P. and Vine, I. (2002). "Bradford: One Year on Breaking the Silences" in Programme for a Peaceful City. Bradford: University of Bradford.

-Singh, R. (2002). "Race Relations Polic ies of the Bradford Metropolitan Council (BMC)", Conference on Applied South Asian Studies Manchester: Manchester University, March, 


\title{
Summary
}

\section{Managing race relations' tensions in multicultural societies: a case study of Bradford in B ritain.}

\author{
Hassen Zriba \\ University of Gafsa, Tunisia
}

\begin{abstract}
Managing cultural differences has become a top priority in many western multicultural societies. Issues of intercultural harmony and social stability loom large in the rhetoric of political governance. Discourses of social cohesion and national unity seem to replace those of multiculturalism and cultural diversity. In this article, I study the discursive consideration of such is sues within Britain in general and Bradford city in particular. A critical interpretive perspective is used to scrutinize the linguistic and the discursive strategies employed by a local race-related report Community Pride not prejudice (2001). It is suggested that such report reflected a growing official tendency to prioritize social unity over cultural diversity. It is perceived as the hegemonic dominant reading of the nature of race relations in contemporary Britain at the beginning of the $21^{\text {st }}$ century. Yet, not hegemony is final. Thus, the dominant ideological inscriptions of the report were also read and decoded differently. Community Pride not prejudice was an official narrative of how ethnic residential segregation contributed immensely to the failure of race relations in Bradford. Nevertheless, other counter-narratives questioned its ideological assumptions and revealed its agenda-setting nature. The outcome of such hegemonic and counter-hegemonic readings of the situation was multiple and polyphonic discursive formations so indicative of the pluralistic nature of a society like that of Britain.
\end{abstract}

Key words: mul ticultur alism, social cohesion, race relations, segregation, di versity 